\title{
'That's more than we know': The Principle of Responsibility and the Common Soldier in William Shakespeare's Plays
}

\author{
Franziska Quabeck
}

This paper considers literary texts that foreground the combatants' view. The focus lies on the soldiers' perspective in general and on just war theory's principle of responsibility in particular. The distinction between jus ad bellum and jus in bello as discussed by just war theorists allows us to distinguish between different spheres of responsibility and this entails that soldiers may be not responsible for the war as such, only for their conduct. However, this view is contested, as many just war theorists today argue that we ought to make a distinction between just and unjust soldiers. This paper discusses literary texts that seem to counter this view. Two playwrights, William Shakespeare and Gregory Burke, writing war plays for the stage over four hundred years apart, go to great lengths to show their audience the common soldiers' perspective on the justice of the wars they fight in. This paper argues that both playwrights draw a line between jus ad bellum and jus in bello. Both Shakespeare and Burke seem to emphasize deliberately that soldiers cannot be held accountable for the injustice of the causes they are obligated to fight for.

William Shakespeare, Gregory Burke, Michael Walzer, Jeff McMahan, jus ad bellum, jus in bello, responsibility, 3Henry VI, 1 Henry IV, 2 Henry IV, Henry V, Black Watch

Franziska Quabeck is assistant professor for English Literary and Cultural Studies at the University of Münster. Her main research areas are Shakespeare and early modern drama, Kazuo Ishiguro and contemporary Anglophone literature and Victorian literature and culture. Recent publications: "Shakespeare's Unjust Wars," Critical Survey 30.1 (2018): 67-80; "Cultural Rights and the Politics of Recognition in Kazuo Ishiguro's Never Let Me Go" in Diaspora, Law and Literature. Proceedings of the Vigoni Talks on Diaspora, Law and Literature. Berlin / New York: Walter de Gruyter, 2016:205-222; Just and Unjust Wars in Shakespeare. Berlin / New York: Walter de Gruyter, 2013.

\section{The Principle of Responsibility}

The focus of this paper lies on the soldiers' perspective in general and on just war theory's principle of responsibility in particular. The question is whether there are two different kinds of responsibility in times of war. In the following, I will juxtapose theoretical considerations with practical views, but I draw those views exclusively from literary examples. I would like to argue that these literary voices might contribute to the philosophical debate that has ensued between different 
proponents of just war theory over the last couple of decades. Michael Walzer has argued that the justice of war and justice in war are independent of one another: "Jus ad bellum requires us to make judgments about aggression and self-defense; jus in bello about the observance or violation of the customary and positive rules of engagement. The two sorts of judgment are logically independent. It is perfectly possible for a just war to be fought unjustly and for an unjust war to be fought in strict accordance with the rules." ${ }^{1}$ While this sounds logical and more or less inconspicuous, this 'independence thesis' nevertheless has a serious implication for the soldier's moral status and their moral responsibility. Since they do not declare war, they are not responsible for it, even if it is unjust. One simply has to distinguish two kinds of responsibility: according to Walzer, we "draw a line between the war itself, for which soldiers are not responsible, and the conduct of the war, for which they are responsible, at least within their own sphere of activity." 2 The distinction allows us to distinguish between different responsibilities and culpabilities in war. If soldiers are responsible for their own conduct, they are potentially culpable if they do wrong. If they are not responsible for the war, they are not liable to be held culpable if it is an unjust war. As Walzer first put it in 1977, "their war is not their crime." 3 Despite the seeming logic of his argument, many theorists question Walzer's independence thesis severely. The most prominent among those is possibly Jeff McMahan, who argues in his book Killing in War (2000) against both the independence of jus ad bellum and jus in bello and against the moral equality of soldiers. His counter arguments have set off a long-lasting debate that continues to this day and this debate lies at the heart of this paper. However, I will not engage in the philosophical exchange, but rather demonstrate that literary texts of different ages share very similar concerns. Just war theory has not only found its way onto contemporary stages, but already features prominently in early modern drama as I hope to show in the following.

In his response to McMahan's criticism of the logical distinction between jus ad bellum and jus in bello, Walzer takes a step back to the basic assumptions made about war to remind us that war is "a coercively collectivizing enterprise" that "overrides individuality." $\mathrm{He}$ argues that theorists of war should not consolidate or sustain this all-encompassing view, but try to restore the soldier's individuality. Interestingly, there are at least one contemporary and one early modern playwright who seem to share this concern. They use their plays to restore the soldier's individuality and they do so with an overt focus on the soldier's responsibility. On August $1^{\text {st }}, 2006$, Gregory Burke's newest play, Black Watch, premiered at the

1 Michael Walzer: Just and Unjust Wars. A Moral Argument with Historical Illustrations. Fifth Edition. New York: Basis Books, 2015, 21.

2 Walzer, Just and Unjust Wars, 6.

3 Walzer, Just and Unjust Wars, 37.

4 Michael Walzer: "Response to McMahan's Paper," Philosophia 34.1 (2006): 43 $45,43$. 
Edinburgh Festival to raving reviews. The play dramatizes the real deployment of the Scottish infantry battalion in the Iraq War in 2004 and is based on interviews with soldiers after their return. It consists almost entirely of verbatim dialogue and thus tells the story from the soldiers' perspective. Their own experience is almost the sole focus of the play and it turns out that they are not only preoccupied with their recollection of battle, but more importantly with their role as soldiers in a war that the public has come to condemn as unjust. The soldier's statements made to one another, but also to the audience, circle around the question of their own responsibility in view of an unjust war. They ask themselves in how far they are accountable, but they also ask themselves in how far the public deems them accountable:

A'right. Welcome to this story of the Black Watch. At first, I didnay want tay day this. I didnay want tay have tay explain myself tay people ay. See, I think people's minds are usually made up about you if you were in the army. [...] And people's minds are made up about the war that's on the way now ay? They are. It's no right. It's illegal. We're just big bullies. $^{5}$

Cammy's use of the plural personal pronoun 'we' is telling: he somehow identifies with the enterprise as a whole, yet seems clearly uneasy about his own role in it. $\mathrm{He}$ feels the need to justify himself, since he has the vague impression that he is blamed for immoral action, but at the same time he is also reluctant to defend himself, because he is just part of a larger enterprise. Through this contradiction, Burke has managed to focus the play on the distinction between the justice of war and the justice in war that the public fails to make. The soldiers are implicated unrightfully in the injustice of the war and Burke uses the stage to rectify their moral status in war. As he stated in an interview with The Observer in 2008: "Why, I wondered, were so many people who were opposed to the Iraq war, for any number of fine principles, also apparently opposed to (or indifferent to) the soldiers, unable to differentiate between the amateurs doing the planning and the professionals doing the dying?" Thus, the play is dedicated specifically to the soldier's perspective which public discourse tends to neglect, although, as Burke emphasizes, soldiers are not naturally responsible for, let alone culpable of the war they fight. His statement shows that one of his crucial interests in bringing this story to the stage was to rectify the assumption that soldiers are somehow to blame for the war. In other words, his crucial, yet apparently unwitting, interest was to draw attention to the distinction between jus ad bellum and jus in bello that,

5 Gregory Burke: The National Theatre of Scotland's Black Watch (London: faber and faber, 2007): 3/4.

6 Euan Ferguson: "Interview with Gregory Burke: 'The Thing About Fife is Its Tribal ... There's a Fierce Loyalty'," The Observer April 13 (2008). Available at: http:// www.guardian.co.uk/stage/2008/apr/13/theatre.edinburghfestival1. 
'That's more than we know'

among other things, frees soldiers from that particular responsibility. Thus, the play's very first lines draw attention to the fact that these soldiers feel the need to justify themselves for actions they actually perceive of as their duty. Their reluctance to speak results from their reluctance to justify themselves for an injustice they do not conceive of as their own. If this war is a crime, it is not their crime and the play points this out. It constitutes a literary attempt to foreground the fact that the soldier is not responsible per se.

Burke's is just one of a number of contemporary plays on the Iraq War, but it differs decisively from others in its obvious focus not only on the combatants' experience, but more importantly on the combatants' feeling of guilt. They cannot help but feel implicated in an immoral endeavor and yet they were never allowed to make an active decision. Thus, Burke manages to turn the audience's attention away from their judgment of the particular war and to the universal question of the individual soldier's role in war. He pushes the specific (im)morality of the Iraq War to the margins in favor of the difficult question of the subaltern's responsibility. The play therefore shows a specific investment in moral issues typically raised and debated by just war theory. It might not be surprising that a play from 2006 takes such matters to heart. It might be more surprising that an early modern writer does the same. Shakespeare is not always a concern of just war theorists, but Shakespeare's plays are much more concerned with the justice of war than his critics have pointed out so far. Many of these plays actually place a specific emphasis not only on the soldier's perspective, but, even more importantly, on the question of their responsibility.

\section{Just War Theory in Shakespeare}

Michael Walzer is among the few just war theorists who have considered Shakespeare in their arguments. As is obvious to anyone familiar with his seminal Just and Unjust Wars from 1977, Walzer does not restrict himself to historical illustrations, but includes literary sources as well. From Euripides to Shakespeare, from Tolstoy to George Orwell, Walzer found scenes, plot elements, dialogues and monologues that helped him illustrate the ethical consideration in his focus, thereby seemingly drawing on fictional literature as a potential contributor to a philosophical debate. Among those illustrations, Shakespeare rises to particular prominence. Walzer quotes his King John, Henry V and Troilus and Cressida for considerations of very different ethical questions. While he uses Shakespeare's Henry to illustrate the injustice of killing prisoners of war, he refers to King John to emphasize the importance of the moral language that we use and he considers a debate on Helen of Troy in Troilus and Cressida as an astute estimation of the proportionality of war. ${ }^{7}$ Although Walzer's interpretation of the literary text is not

7 See Walzer, Just and Unjust Wars, 17-29; 296 and 120. 
necessarily convincing in all cases, his strategy nevertheless draws attention to the fact that literature might have more to contribute to just war theory than is commonly thought. A close examination of the Shakespeare text concedes the point very quickly: the collocation 'just war' is ubiquitous in the plays and it becomes obvious that there is a strong undercurrent on the justice of wars. This is even more interesting as Shakespeare scholars have not always noticed this specific ethical consideration of war in the plays. There is a long tradition of arguments for Shakespeare's pacifism and an equally long tradition that has argued that Shakespeare glorifies war. These two approaches respectively assume a strong influence of Erasmus's writings vis-à-vis Machiavelli's writings in most of the plays. Prima facie, there is reason to believe both. Henry VI is a notable pacifist in Shakespeare, whose arguments against war based on the principle that violence among Christians can never be permitted: "I always thought | It was both impious and unnatural | That such immunity and bloody strife | Should reign among professors of one faith." (1Henry VI, 5.1.11-14) Throughout all the three plays on his reign, the character Henry VI argues consistently against violence of any kind, to hold "slaughtering hands" and "keep the peace." (1Henry VI, 3.1.87) He symbolizes an equation of Christianity and pacifism, appealing to his opponents' faith to pacify them and more or less directly refers to Aquinas' dictum that churchmen and priests especially shall not involve themselves in war: "Who should be pitiful, if you be not? | Or should study to prefer a peace | If holy churchmen take delight in broils?" (1Henry VI, 3.1.110-112) Piety and pacifism seem inextricably linked and the ensuing horrors of the Wars of the Roses in Shakespeare's dramatization seem to prove Henry's point. Nothing seems just that causes such a pitiful spectacle. Thus, many Shakespeare scholars have preferred to see the playwright as belonging to the pacifist camp. Steven Marx, among others, has claimed that Shakespeare developed from "a partisan of war to a partisan of peace" and that his late play Troilus and Cressida "condemns war and those who make it." 8

There is one obvious objection to this thesis: if Henry VI is Shakespeare's upholder of the pacifist principle, one has to note nevertheless that he is entirely unsuccessful and in his failure as king even culpable. All opponents overrule him because he is unwilling to use force in the defense of his kingdom, thereby ironically causing the deaths of hundreds of people. His pleas and prayers remain ineffectual, which renders him one of the more incapable kings in Shakespeare's drama. "[B]etter fitted for the role of saint than of king," in Harold Goddard's words, Henry hands over his kingdom to Machiavellian schemers, whose realpolitik proves far more effectual. The dominance of this approach to war, which

8 Steven Marx, "Shakespeare's Pacifism,” Renaissance Quarterly 45.1 (1992): 49-51, 50 and 69 .

9 Harold C. Goddard: The Meaning of Shakespeare. Vol. I (Chicago and London: The University of Chicago Press, 1960), 32. 
'That's more than we know'

Walzer commonly terms 'realism,' and which can be found in Shakespeare from Richard III to Macbeth, has convinced other critics that Shakespeare might really be a partisan of war. ${ }^{10}$ His alleged depiction of 'the mirror of all Christian kings' in the character of Henry V and the enthusiasm of the play's chorus seem to support a realist approach to war, but as Norman Rabkin showed as early as 1977, it is just as perfectly possible to read this play as a condemnation of war. ${ }^{11}$ Rabkin's seminal text on Henry $V$ was among the first to introduce the notion of Shakespeare's famous ambiguity as a technique, which eventually leaves things unresolved: "Always the dramatic structure sets up the opposed elements as equally valid, equally desirable, and equally destructive, so that the choice that the play forces the reader to make becomes impossible." 12 Shakespeare's "radical ambiguity" 13 or "ambidextrousness" not only when it comes to the subject of war. However, as I have argued elsewhere, one need not confine oneself to the thesis that Shakespeare leaves the moral question of war necessarily unresolved. ${ }^{15}$ The third possibility of explanation lies in just war theory as a common ground between pacifism and realism.

Since just war theory neither argues for the general impermissibility of war such as pacifism does, nor postulates that war is a condition that is necessarily exempt from moral judgement, it offers a third approach to William Shakespeare's plays that has rarely been applied, although the general terminology is "ubiquitous" in the drama. ${ }^{16}$ In 3 Henry VI, Warwick claims, "York in justice puts his armour on." (2.2.130) In Richard III, Richmond states, "God, and our good cause, fight upon our side." (5.3.241) Henry IV claims in the first part of the play series, "God befriend us as our cause is just!"' (1Henry IV, 5.1.120) Hotspur utters in the same play the belief that "the arms are fair, $\mid$ When the intent of bearing them is just." (1Henry IV, 5.2.87/88) In the second part of the series the Archbishop explains that he has "in equal balance justly weigh'd" their cause for war against the costs and finds their "griefs heavier than their offences" (2Henry IV, 4.1.67-69), but Westmoreland claims, their "cause is best." (2Henry IV, 4.1.156)

10 See, among others, Paul Jorgensen: Shakespeare's Military World (Berkely et al.: University of California Press, 1956) and Tim Spiekerman, Shakespeare's Political Realism (Albany: State University of New York Press, 2001).

11 See Norman Rabkin: "Rabbits, Ducks and Henry V," Shakespeare Quarterly 28.3 (1977), 279-296.

12 Norman Rabkin: Shakespeare and the Common Understanding (New York: The Free Press, 1967), 12.

13 R. S. White: "Pacifist Voices in Shakespeare," Parergon 17.1 (1999), 135-162, 143.

14 Jonathan Bate: The Genius of Shakespeare (London: Picador, 1997), 328.

15 See Franziska Quabeck: Just and Unjust Wars in Shakespeare (Berlin / New York: Walter de Gruyter, 2013).

16 See Paola Pugliatti: Shakespeare and the Just War Tradition (Farnham: Ashgate, 2010), 1 . 
Henry Vasks whether he may "with right and conscience" (Henry V,1.2.96) make his claim on France and in conversation with his soldiers claims that his cause is just and "his quarrel honourable." (Henry $V, 4.1 .126)$ These references are merely exemplary of numerous similar utterances in many of the plays usually attributed to Shakespeare, but the same language increasingly finds itself in Shakespeare criticism after the millennium. In 2000, John Mark Mattox published an analysis of Henry $\mathrm{V}$ as a just warrior and references in Shakespeare criticism to 'just wars' increased notably in the following years. ${ }^{17}$ Michael Hattaway claims, "the Battle of Bosworth in Richard III may be the only example of a just war in the canon." 18 Nicholas Grene states, "when an armed force appears under the command of Richmond, it is to be welcomed as the just war to end the cycle of violence."19 Simon Barker refers to Richmond's "lukewarm version of the just war ethic"20 and R. A. Foakes has claimed, "Shakespeare seems especially interested in [...] the emerging question whether there can be a just war." ${ }^{21}$ A closer look at Shakespeare's account of war shows that this is true and it reveals that many of the canonical precepts and principles of just war theory have found their way into Shakespeare's plays. Among those are the three classic principles of legitimate authority, just cause and right intention, as well as the principle of proportionality and certain jus in bello-precepts. Moreover, it turns out that the logical distinction made by Walzer between jus ad bellum and jus in bello is equally important in Shakespeare's plays and lends the combatants' perspective a specific emphasis that is quite unusual for early modern drama. I would like to argue in this article that just like Burke, Shakespeare uses the fictional possibilities of the stage in order to foreground the soldiers' perspectives, thereby giving voice to a subaltern not generally heard in early modern drama. Moreover, once given the opportunity, the soldiers themselves put specific emphasis on the distinction between jus ad bellum and jus in bello and draw the respective conclusions for their own moral responsibility in war.

17 See John Mark Mattox: "Henry V: Shakespeare's Just Warrior," War, Literature \& the Arts 12.1 (2000), 30-53.

18 Michael Hattaway: "The Shakespearean History Play" in The Cambridge Companion to Shakespeare's History Plays, ed. Michael Hattaway (Cambridge: CUP, 2002), 3-24, 14.

19 Nicholas Grene: Shakespeare's Serial History Plays (Cambridge: CUP, 2002), 92.

20 Simon Barker: War and Nation in the Theater of Shakespeare and His Contemporaries (Edinburgh: Edinburgh University Press, 2007), 128.

21 R. A. Foakes: Shakespeare and Violence (Cambridge: CUP, 2003), 83. 
'That's more than we know'

\section{Shakespeare's Common Soldiers}

One could argue that 'soldier' is a difficult military term to apply to Shakespeare's characters, because most of them are not 'only' soldiers, but rather kings, knights and noblemen of different ranks. King Richard III and King Henry V function as soldiers in the field no less so than Hotspur, who sees his sole raison d'être in chivalrous conduct in war. However, Shakespeare makes a clear distinction between those who fight in wars they have chosen or declared and those who are drawn into the mechanism on very different conditions. Richard dies in a war of his own making, so his death is not a sacrifice for an ulterior goal, but rather a consequence of his aggression and such is the case with similar main characters, who dedicate themselves to causes they believe in, be they justified in doing so or not. The interest of this paper, however, lies in those Shakespeare characters who are at the very bottom of the military hierarchy and who have little or no say in their own military implementation.

These 'common' soldiers have received disparate reviews from Shakespeare critics, yet most critics judge them quite severely. One has to concede that at first sight, these characters do not seem to come off favorably in terms of honourable conduct. While Shakespeare's knights such as Talbot in Henry VI cheer their followers on in battle with cries like "Hark, countrymen - either renew the fight | Or tear the lions out of England's coats" (1Henry VI, 1.5.27/28) or "Die all; die merrily" (1Henry IV, 4.1.133) like Hotspur, the common soldiers more often than not express quite different views and considerably less enthusiasm. Talbot's patriotism, for instance, is met with soldiers who, according to his description, "like to whelps [...] crying run away." (1Henry VI, 1.5.26) In 2Henry IV, the Archbishop of Canterbury's forces defect and "[l]ike youthful steers unyok'd [...] take their courses | East, west, north, south; or, like a school broke up, | Each hurries towards his home and sporting place." (4.2.103-105) And when Henry V urges "[o]nce more unto the breach" (Henry $V, 3.1 .1$ ), the dialogue between those at the very bottom of the hierarchy on the other side of the stage creates a nice juxtaposition of heroism with disillusionment:

Nym Pray thee, Corporal, stay; the knocks are too hot, and for mine own part I have not a case of lives. The humour of it is too hot, that is the very plain song of it. [...]

Boy Would I were in an alehouse in London! I would give all my fame for a pot of ale and safety. (Henry V, 3.2.3/4, 12/13)

These characters sing the 'plain' song, i.e. they draw a realistic picture of the war they find themselves in and the overt irony lies of course in the fact that whether they fight or not and win or not, they will never receive any fame for it - significantly, the boy remains nameless. They give voice to their very own perspective on this military engagement, but since this creates such a stark contrast to the 
artificial heroism the play portrays, their position seems not only funny, as it is surely intended to be, but also cowardly to the point of dishonourable. Thus, critics have felt inclined to argue that Shakespeare generally "resists giving sympathy to the commonality."22 It seems that he merely employs the roles to entertain the masses, since dialogues such as these would "ring true not only to the gentry in Shakespeare's audiences but to practically everyone who could afford a place in the theatre." ${ }^{23}$ These common soldiers are exposed to ridicule in more than one play and their general unwillingness to die serves for more than one comic scene so necessary for theatrical entertainment. Either they try to avoid service, arguing that "there are other men fitter to go out than I" (2Henry IV,3.2.114/115) or they succumb to tragicomic fatalism: "he that dies this year is quit for the next." (2Henry IV,3.2.233) Yet, while the comedy might be overt, it is very clear that this discourse among the common soldiers has a serious undertone, which reveals that they are victims, rather than soldiers. This injustice is emphasized in three emblematic scenes in Shakespeare: (1) the first draws a realistic picture of Elizabethan levy practices, (2) the second stages an unrealistic moral argument between the soldier at the bottom and the King at the top of the military hierarchy and (3) the third is an allegorical stage tableau that embodies the fatality of an equation of ad bellum and in bello.

(1) The common soldiers' reluctance to go into battle in 2Henry IV is partly explained by Sir John Falstaff, their less than scrupulous captain, who gives a rather grim account of Elizabethan levy practices:

I have misused the King's press damnably. I have got, in exchange of a hundred and fifty soldiers, three hundred and odd pounds. [...] I pressed men none but such toasts-andbutter, with hearts in their bellies no bigger than pins' heads, and they have bought out their services; and now my whole charge consists of [...] such as indeed as were never soldiers, but discarded unjust servingmen, younger sons to younger brothers, revolted tapsters and ostlers trade-fallen [...]. No eye hath seen such scarecrows. (1Henry IV, 4.2.11-14, 20-24, 26-29, 37)

As a representative of typical Elizabethan captains, Falstaff describes that he has let qualified men buy themselves out of service and that he has drawn those without choices instead. As Corelli Barnett states, the "rich but timid could provide substitutes; yet another form of corruption guaranteeing the Queen useless recruits." ${ }^{24}$ The comedy therefore results partly from the popular Falstaff

\section{Jorgensen, Shakespeare's Military World, 147.}

23 J. R. Hale: "Shakespeare and Warfare" in William Shakespeare. His World, His Works, His Influence. Vol. I, ed. John F. Andrews (New York: Charles Scribner's Sons, 1985), 85-98, 92.

24 Corelli Barnett: Britain and Her Army 1509-1970. A Military, Political and Social Survey (London, Allen Lane The Penguin Press, 1970), 42. 
figure, but also from the audience's familiarity with Elizabethan levy practices. Falstaff's description obviously rings true for an audience, since "the entire speech highlights well-known abuses in the Elizabethan recruiting system." ${ }^{25}$ As C. G. Cruickshank has shown,

towards the end of the reign it was reported that [the trained bands] were full of worthless creatures trying to escape foreign service. They were intended for gentlemen, farmers, and better-class yeomen and labourers, but in fact they were full of servants and members of the poorer classes. ${ }^{26}$

Significantly, the soldiers Falstaff speaks about never appear to the audience. He only reports in the last act, "I have led my ragamuffins where they are peppered; there's not three of my hundred and fifty left alive, and they are for the town's end to beg during life." (1Henry IV, 5.3.35-38) Since they are not properly equipped to go to war, almost all of them die a pointless death. Furthermore, in another historical reference to the Elizabethan military, Falstaff reminds us that those who survive cannot expect compensation, let alone pension. An Elizabethan soldier who survived the war had little to gain from their survival. ${ }^{27}$ Thus, for an Elizabethan audience the comedy results from the parody of their reality, but there is also a serious undercurrent to the scene. Falstaff's comic interlude exposes him as the representative of the soldiers' oppression and Shakespeare makes a point of their absence. Falstaff speaks of a nameless and faceless collective off-stage, thereby overriding the soldiers' individuality. Patricia Cahill has pointed out that the play "relegates impressments to the margins - to the shady dealings that happen offstage," 28 but the blatant absence of these soldiers is juxtaposed with their entries in the later play. 2Henry $I V$ exposes the common soldiers' plight embodied in characters, who express their reluctance to go to war in order to alert the audience to the fact that a common soldier pressed into service has very little chance of survival. Their unwillingness to go to war results from their realistic perspective on the chance of survival. Therefore, when Feeble argues in the scene described above, "I care not, a man can die but once, we owe God a death" (2Henry IV, 3.2.229/230), he is less cynical than simply realistic. Shakespeare gives his subalterns the voice to express this. Thus, while their seeming cowardice provides comedy for the stage, it also implies an accusation of the injustice of their oppression.

25 William Shakespeare: King Henry IV, Part One, ed. David Scott Kastan. The Arden Shakespeare Third Series (London: Thomson Learning, 2002), 289, fn. 12-47.

26 C. G. Cruickshank: Elizabeth's Army (Oxford: Clarendon Press, 1966), 25.

27 See Wallace T. MacCaffrey: Elizabeth I. War and Politics 1588-1603 (Princeton, New Jersey: Princeton University Press, 1992), 46 ff.

28 Patricia A. Cahill: Unto the Breach. Martial Formations, Historical Trauma, and the Early Modern Stage (Oxford: OUP, 2008), 84. 
(2) The assumption that this is not a coincidence or merely comic interest is confirmed by an even more pointed and overtly political scene in Henry $V$. Here, the victims of immoral levy practices are not only given a voice, but they are also given the opportunity to challenge their superior. In a fictitious scene that is dramatically unnecessary and historically inaccurate, the common soldiers may openly question the justice of the war and their participation in it. Facing the morning of the Battle of Agincourt, the named soldiers Bates and Williams express their realistic life expectancy: "We see yonder the beginning of the day, but I think we shall never see the end of it." (Henry V,4.1.90/91) The subaltern voice of the common soldiers dominates the dialogue, enabled by Shakespeare in a seemingly deliberate deviation from both his sources and historical accuracy. As Phyllis Rackin has pointed out, in order to make these voices heard, a "recourse to fiction is necessary because common soldiers had no place in the historiographic record." 29 Thus, these soldiers do not only have the opportunity to draw attention to their plight, but, even more importantly, they can voice that responsibility is their greatest concern. In a dramatic encounter with the King in disguise, they are given the opportunity to question the justice of the war and they openly argue for the distinction between ad bellum and in bello. When Henry claims his war to be "just" and "honourable," Williams frankly replies, "That's more than we know": "Ay, or more than we should seek after, for we know enough if we know we are the King's subjects. If his cause be wrong, our obedience to the King wipes the crime of it out of us." (Henry V, 4.1.127-131) As Walzer has it, "their war is not their crime." ${ }^{30}$ It lies within the King's responsibility that his cause be just and not within the soldier's. Their subjection to the crown and their military service in the King's name means that they do not have to answer for the justice of the war. They only have to answer for their own conduct. The dialogue thus anticipates the distinction made in just war theory centuries later with astounding accuracy. As Walzer argues, in direct reference to Shakespeare's scene,

by and large we don't blame a soldier, even a general, who fights for his own government. $\mathrm{He}$ is not the member of a robber band, a willful wrongdoer, but a loyal and obedient subject and citizen, acting sometimes at great personal risk in a way he thinks is right. [...] The atrocities he commits are his own; the war is not. ${ }^{31}$

The inclusion of the dialogue between the soldiers and the King thus draws the attention specifically to this distinction between responsibilities and deliberately foregrounds the perspective of those who die in war. They have the opportunity to argue for their right to be freed from the responsibility for the war in an anach-

29 Phyllis Rackin: Stages of History. Shakespeare's English Chronicles (London: Routledge, 1990), 225.

30 Walzer, Just and Unjust Wars, 37.

31 Walzer, Just and Unjust Wars, 39. 
ronistic confirmation of Walzer's and refutation of McMahan's assumptions. Moreover, the fact that Shakespeare has to deviate from the historical record gives the implications for the justice of the war even more weight, according to Rackin: "Only by moving beyond the boundaries of historiographic discourse into the liberties of theatrical invention can Shakespeare find a place for the common soldiers in historical drama." ${ }^{32}$

(3) The third scene in support of my argument that Shakespeare tries to emphasize the combatants' perspective and the distinction between the justice of war and justice in war is included in one his earliest plays, 3Henry VI. It seems that while Shakespeare's themes increase in complexity over the course of his career, as critics typically observe, the soldier's perspective finds its way into the plays as early as 1593 . Here, a single stage tableau captures the distinction of ad bellum and in bello, the role of the soldier and their responsibility. Amidst the dramatization of the Wars of the Roses, two character pairs enter the stage from different sides. Once again, they remain nameless, thereby metonymically representing all soldiers that fight and die in this war. On the left, a son has killed his father, since both were drawn from different sides of the opposition. On the right, a father has killed his son for the same reason:

O pity, God, this miserable age!

What stratagems, how fell, how butcherly,

Erroneous, mutinous and unnatural,

This deadly quarrel daily doth beget! [...]

I'll bear thee hence, and let them fight that will

For I have murdered where I should not kill.

(3Henry VI, 2.5.88-91; 121/122)

The tableau visibly juxtaposes the victims of an unjust war. Their anonymity makes them metonymies for all the soldiers dying in this war and the deaths within the families serve as metaphors of the unnatural disruption of a state at war with itself. This particular dilemma has ensued due to coercion, which represents the "peculiar horror of war," according to Walzer, since "force is used by and against men as loyal or constrained members of states and not as individuals who choose their own enterprises and activities." ${ }^{33}$ The injustice of the war is such that even morally irreprehensible soldiers now come to feel guilty. The juxtaposition of "killing" and "murdering" draws attention to the fact that the soldiers no longer feel their duty relieves them of their responsibility. Rather, the injustice of the war is such that their actions are consequentially unjust too. They are implicated in the immorality and therefore do not only have to die in vain, but also stand culpable for a crime that is not theirs. In addition to all of this, both characters represent

32 Rackin, Stages of History, 165.

33 Walzer, Just and Unjust Wars, 70. 
hundreds of soldiers who die in vain. The war has pitted family against family and neither side seems to know the cause of war. It has become void, which means that human beings die unnecessarily - this is one of the greatest crimes of war. As Walzer points out, "it still seems important to say of those who die that they did not die in vain":

There must be purposes that are worth dying for, outcomes for which soldiers' lives are not too high a price. The idea of a just war acquires the same assumption. A just war is one that it is morally urgent to win, and a soldier who dies in a just war does not die in vain. ${ }^{34}$

\section{Conclusion}

The setup of the scene, the juxtaposition of interchangeable men from either side of the conflict, makes it visible for the audience that these soldiers die in vain, for they die in an unjust war. As Simon Barker argues, "the formulaic imagery of tragic death undermines its potential to smooth over and institutionalise wasteful death $[\ldots] .{ }^{35}$

Once again, Shakespeare includes a scene without apparent necessity to voice the subaltern's perspective in a way that responds uncannily accurately to contemporary concerns of just war theory. This brings me back to my general argument: while present-day just war theorists have tended for quite a while now to heap the burden of injustice not only on those who make war, but also on those who die in it, Shakespeare's plays seem to present us with arguments in favor of the moral equality of soldiers. He gives his common soldiers plenty of opportunities to insist on the distinction between ad bellum and in bello and his plays seem to draw deliberate attention to the individual combatants' perspectives. Thus, far from remaining ambiguous on the matter, Shakespeare clearly distinguishes the justice and injustice of and in wars with notable priority for the exposition of the plight of the soldier.

Soldiers are more often than not blamed for the injustice of a war they are not responsible for and apparently both William Shakespeare and Gregory Burke, writing over four hundred years apart, have felt the need to point this out. Burke's play, with which I opened the discussion, makes this point as follows: "It takes three hundred years to build an army that's admired and respected around the world. But it only takes three years pissing about in the desert in the biggest western foreign policy disaster ever to fuck it up completely." (Black Watch, 70) In conclusion, Burke and Shakespeare seem to do a very similar thing. They use their plays to foreground the combatants' perspective and by doing so, they point us towards the logical distinction between jus ad bellum and jus in bello. Only if we

34 Walzer, Just and Unjust Wars, 110.

35 Barker, War and Nation, 124. 
accept the independence thesis Walzer puts forth, it seems, is it possible to argue that soldiers are not responsible for the war per se, but only for their own conduct. This is exactly what McMahan has tried to refute. Far be it from me to contest either claim. However, one cannot help but observe that both William Shakespeare's and Gregory Burke's plays ascribe responsibility to those who make wars and generate empathy for those who die in them. War overrides individuality; it is one of its most tragic characteristics that its victims remain invisible, impersonal, anonymous - unless they enter the stage, perhaps. Almost 400 years lie between Shakespeare's and Burke's productions for the theatre - the fact that they should share such similar concerns might indicate that literature might very well have the potential to contribute to the ethical debate in much the same way as Walzer first made use of it exactly forty years ago.

\section{References}

Barker, Simon: War and Nation in the Theater of Shakespeare and His Contemporaries. Edinburgh, Edinburgh University Press, 2007.

Barnett, Corelli: Britain and Her Army 1509-1970. A Military, Political and Social Survey. London, Allen Lane The Penguin Press, 1970.

Bate, Jonathan: The Genius of Shakespeare. London, Picador, 1997.

Burke, Gregory: The National Theatre of Scotland's Black Watch. London, faber and faber, 2007.

Cahill, Patricia A.: Unto the Breach. Martial Formations, Historical Trauma, and the Early Modern Stage. Oxford, OUP, 2008.

Cruickshank, C. G.: Elizabeth's Army. Oxford, Clarendon Press, 1966.

Ferguson, Euan: "Interview with Gregory Burke: 'The Thing About Fife is Its Tribal ... There's a Fierce Loyalty'," The Observer April 13 (2008). Available at http://www. guardian.co.uk/stage/2008/apr/13/ theatre.edinburghfestival1.

Foakes, R. A.: Shakespeare and Violence. Cambridge, CUP, 2003.

Goddard, Harold C.: The Meaning of Shakespeare. Vol. I. Chicago and London, The University of Chicago Press, 1960.

Grene, Nicholas: Shakespeare's Serial History Plays. Cambridge, CUP, 2002.

Hale, J. R.: "Shakespeare and Warfare" in William Shakespeare. His World, His Works, His Influence. Vol. I, ed. John F. Andrews. New York, Charles Scribner's Sons, 1985, 85-98.

Hattaway, Michael: "The Shakespearean History Play" in The Cambridge Companion to Shakespeare's History Plays, ed. Michael Hattaway. Cambridge, CUP, 2002, 3-24.

Jorgensen, Paul: Shakespeare's Military World. Berkely et al., University of California Press, 1956.

Marx, Steven: "Shakespeare's Pacifism," Renaissance Quarterly 45.1 (1992), 49-51.

Mattox, John Mark: "Henry V: Shakespeare's Just Warrior," War, Literature \& the Arts 12.1 (2000), 30-53.

MacCaffrey, Wallace T.: Elizabeth I. War and Politics 1588-1603. Princeton, New Jersey, Princeton University Press, 1992. 
Pugliatti, Paola: Shakespeare and the Just War Tradition. Farnham, Ashgate, 2010.

Quabeck, Franziska: Just and Unjust Wars in Shakespeare. Berlin / New York, Walter de Gruyter, 2013.

Rabkin, Norman: "Rabbits, Ducks and Henry V," Shakespeare Quarterly 28.3 (1977), 279-296.

Rabkin, Norman: Shakespeare and the Common Understanding. New York, The Free Press, 1967.

Rackin, Phyllis: Stages of History. Shakespeare's English Chronicles. London, Routledge, 1990.

Shakespeare, William: King Henry VI, Part One, ed. Edward Burns. The Arden Shakespeare Third Series. London, Thomson Learning, 2000.

Shakespeare, William: King Henry VI, Part Three, eds. John D. Cox and Eric Rasmussen. The Arden Shakespeare Third Series. London, Thomson Learning, 2001.

Shakespeare, William: King Richard III, ed. James R. Siemon. The Arden Shakespeare Third Series. London, Thomson Learning, 2009.

Shakespeare, William: King Henry IV, Part One, ed. David Scott Kastan. The Arden Shakespeare Third Series. London, Thomson Learning, 2002.

Shakespeare, William: King Henry IV, Part Two, ed. A. R. Humphreys. The Arden Shakespeare Second Series. Walton-on-Thames, Methuen \& Co. Ltd, 1966.

Shakespeare, William: King Henry V, ed. T. W. Craik. The Arden Shakespeare Third Series. Walton-on-Thames, Thomas Nelson \& Sons Ltd, 1995.

Spiekerman, Tim: Shakespeare's Political Realism. Albany, State University of New York Press, 2001.

Walzer, Michael: “Response to McMahan's Paper," Philosophia 34.1 (2006), 43-45, 43. Walzer, Michael: Just and Unjust Wars. A Moral Argument with Historical Illustrations. Fifth Edition. New York, Basic Books, 2015.

White, R. S.: "Pacifist Voices in Shakespeare," Parergon 17.1 (1999), 135-162.

Franziska Quabeck, English Department, WWU Münster, Johannisstr. 12-20, 48143 Münster, Germany, e-mail: fquabeck@uni-muenster.de

Citation: Quabeck, Franziska: “That's more than we know': The Principle of Responsibility and the Common Soldier in William Shakespeare's Plays", in: Kallhoff, Angela / Schulte-Umberg, Thomas (eds.): Moralities of Warfare and Religion (J-RaT 2018 / 1) pp. 38-52.

Datum der Publikation: 16.07.2018 